\title{
PENGEMBANGAN KETRAMPILAN SOSIAL SISWA PADA PEMBELAJARAN IPS BERBASIS KEUNGGULAN LOKAL MELALUI PENERAPAN RECIPROCAL LEARNING BERBANTU MEDIA CERITA DAN METRIK INGATAN
}

\author{
Ika Oktavianti, M.Pd., Drs. Mohammad Kanzunnudin, M.Pd. \\ Pendidikan Guru Sekolah Dasar \\ Fakultas Keguruan dan Ilmu Pendidikan \\ Email: ioktavianti@ymail.com, mohammad kanzunnudin@yahoo.com
}

\begin{abstract}
ABSTRAK
Pembelajaran IPS mempunyai tujuan utama untuk mengembangkan karakteristik waga negara Indonesia yang baik khususnya dalam cara berfikir, bersikap dan berperilaku sosial dalam hidup bermasyarakat. Berdasarkan tujuan utama tersebut, pembelajaran IPS tidak hanya menekankan aspek pengetahuan tetapi harus pula mengembangkan ketrampilan sosial siswa untuk mewujudkan tujuan bersikap dan berperilaku sosial dalam hidup bermasyarakat. Ketrampilan sosial dapat dikembangkan pada peserta didik jika dalam pelaksanaan pembelajaran, guru menerapkan pendekatan, model dan media pembelajaran yang tepat.

Penelitian ini merupakan field research (penelitian lapangan) dengan menggunakan mixed methods (metode kombinasi). Subyek penelitian ini adalah siswa kelas V SD di Kecamatan Bae Kabupaten Kudus. Pengumpulan data menggunakan metode observasi, wawancara, dokumentasi dan angket. Teknik pemerikasaan keabsahan data menggunakan triangulasi sumber data.

Hasil penelitian menunjukkan: 1) reciprocal learning berbantu media cerita dan metrik ingatan pada pembelajaran IPS berbasis keunggulan lokal dapat diterapkan dalam menggembangkan ketrampilan sosial siswa, 2) terjadi pengembangan ketrampilan sosial pada siswa setelah diterapkannya reciprocal learning berbantu media cerita dan metrik ingatan pada pembelajaran IPS berbasis keunggulan lokal, dan 3) perbedaan individu terutama dalam kesiapan belajar yaitu siswa yang mengalami gangguan disabilitas intelektual, slow learner, disleksia, disgrafia, dan anak yang mempunyai kurangnya kerapian kurang merupakan faktorfaktor yang mempengaruhi pengembangan ketrampilan sosial pada pembelajaran IPS berbasis keunggulan lokal.
\end{abstract}

Kata Kunci: Ketrampilan Sosial, Pembelajaran IPS, Keunggulan Lokal, Reciprocal Learning, Media Cerita, Metrik Ingatan 
Social learning has the main goal to develop the characteristics of a good citizen of Indonesia, especially in the way of thinking, being and social behavior in social life. Based on the main goal, social learning not only emphasizes the aspect of knowledge but also to develop the social skills of students to realize the goal of being and behaving in social life. Social skills can be developed in learners if the implementation of learning, teachers implement the right approach, models and learning media.

This research is a field research (fieldwork) by using mixed methods. The subjects of this study is the fifth grade elementary school students in the District Bae Kudus. Data collection using the method of observation, interviews, documentation and questionnaires. The validity of the data using the triangulation of data sources technique.

The results showed: 1) Reciprocal learning assisted stories media and memory metrics in social learning local advantages can be applied to develop social skills of students, 2) occured the development social skills of students after the implementation of reciprocal learning assisted stories media and memory metrics in social learning local advantages, and 3) individual differences, especially in readiness of learning that students who have intellectual disabilities disorders, slow learner, dyslexia, dysgraphia, and children who has a lack of neatness less are the factors that influence the development of social skills in social studies of local advantages.

Key Words: Social Skill, Social Studies, Local Advantages, Reciprocal Learning, Stories Media, Memory Metrics

\section{PENDAHULUAN}

Setiap manusia mempunyai banyak kecerdasan yang perlu diolah dan dikembangkan. Dalam mengembangkan kecerdasan manusia ini, pendidikan mempunyai peran yang sangat penting, sesuai yang disampaikan dalam UndangUndang No. 20 Tahun 2003 mengenai sistem pendidikan nasional yang berbunyi "pendidikan adalah usaha sadar dan terencana untuk mewujudkan suasana belajar dan proses pembelajaran agar peserta didik secara aktif mengembangkan potensi dirinya untuk memiliki kekuatan spiritual, keagamaan, pengendalian diri, kepribadian, kecerdasan, akhlak mulia, serta ketrampilan yang diperlukan dirinya, masyarakat, bangsa dan negara". Undangundang tersebut menunjukkan bahwa pendidikan mempunyai peran yang penting dalam mengembangkan kecerdasan manusia baik kecerdasan intelektual atau Intelligence Quotient (IQ), kecerdasan emosional atau 
Emotional Quotient (EQ), dan kecerdasan spiritual atau Spiritual Quotien (SQ).

Berangkat dari pengembangan ketiga kecerdasan tersebut, persoalan yang terjadi dalam masyarakat,hanya kecerdasan intelektual atau Intelligence Quotient (IQ) yang lebih banyak ditekankan pengembangannya. Kecerdasan ini umunya terus dikembangkan oleh para orang tua maupun para pendidik karena dipacu adanya suatu kebanggaan bila nilai rapor anak/siswa tinggi di sekolah. Tidak hanya di pendidikan formal saja, para orang tua juga meminta anaknya untuk mengembangkan kecerdasan intelektual ini dengan mengharuskan anak untuk mengikuti les pelajaran les di luar sekolah. Kondisi ini menyebabkan orang tua bahkan pendidik mengabaikan kedua kecerdasan yang lain yaitu kecerdasan emosional atau Emotional Quotient (EQ) dan kecerdasan spiritual atau Spiritual Quotien (SQ).

Menurut Akhmad Muhaimin Azzet (2010:42-43), sangat dibenarkan apabila memacu anak agar mempunyai kecerdasan intelektual yang baik, namun jangan sampai mengembangkan kecerdasan intelektual hingga melupakan untuk mengembangkan kecerdasan yang lainnya, yang dalam hal ini terutama kecerdasan emosional merupakan kecerdasan sosial. Lebih lanjut lagi, Daniel Goleman dalam bukunya yang berjudul "Emotional Intelligence" menyatakan bahwa kontribusi IQ bagi keberhasilan seseorang hanya sekitar 20\% dan sisanya $80 \%$ ditentukan oleh sederet faktor yang disebut sebagai kecerdasan emosional (Akhmad Muhaimin Azzet, 2010:36). Disinilah pendidikan mempunyai peran yang sangat penting dalam membantu manusia menumbuhkembangkan potensi-potensi kemanusiaannya melalui pengembangan kecerdasan sosial.

Kecerdasan Sosial sangat penting untuk dikembangkan agar seseorang bisa sukses dalam meniti karir, baik itu usaha secara mandiri maupun berkerja di sebuah lembaga atau perusahaan. Hal ini dikarenakan bila seseorang memiliki kecerdasan sosial maka ia mampu untuk menjalin kerjasama, mempunyai rasa empati, atau piawai dalam menjalin komunikasi. Daniel Goleman dalam karyanya "Social Intelegence" menjelaskan bahwa setiap individu mempunyai pembawaan yang integral, 
seperti kerjasama, empati, dan sifat mementingkan kepentingan orang lain (Akhmad Muhaimin Azzet, 2010:39-41). Berdasarkan pendapat tersebut, pembelajaran seharusnya tidak hanya menekankan pada aspek kognitif saja, tetapi pula juga menekankan aspek afektif dan psikomotorik.

Pengajaran IPS di sekolah merupakan salah satu mata pelajaran akademis yang sengaja dirancang dan dilaksanakan untuk mengembangkan karakteristik warga negara Indonesia yang baik khususnya dalam cara berfikir, bersikap dan berperilaku sosial dalam hidup bermasyarakat (Udin Saripudin Winataputra 1989:2). Hal ini menunjukkan bahwa IPS bertujuan meningkatkan dan menumbuhkan pengetahuan, kesadaran dan sikap sebagai warga negara yang bertanggung jawab, menuntut pengelolaan pembelajaran secara dinamis dengan mendekatkan siswa kepada realitas objektif kehidupannya, maka dalam pembelajaran IPS, guru perlu melatih ketrampilan sosial untuk mengembangkan kecerdasan sosial anak.

\begin{tabular}{cccc}
\multicolumn{3}{c}{ Berdasarkan } & Undang-Undang \\
Nomor $\quad 22$ & Tahun & 1999 tentang
\end{tabular}

pemerintah daerah menuntut pelaksanaan otonomi daerah dan wawasan demokrasi dalam penyelenggaraan pendidikan, maka pembelajaran IPS pada penelitian ini akan disajikan pembelajaran IPS yang berbasis keunggulan lokal. Pembelajaran IPS yang berbasis keunggulan lokal didukung Peraturan Pemerintah Nomor 19 Tahun 2005 Bab III Pasal 14 Ayat 1 bahwa kurikulum untuk SMP/MTS/SMPLB atau bentuk lain yang sederajat, dapat memasukkan pendidikan berbasis keunggulan lokal. Melalui pembelajaran berbasis keunggulan lokal, peserta didik didorong untuk mencintai tanah kelahirannya, berjuang untuk membesarkannya, dan gigih mengembangkan semua potensinya daerahnya agar mampu berkembang pesat seiring dengan tuntutan era globalisasi dan informasi.

Pengembangan ketrampilan sosial tidak akan berjalan tanpa didukung adanya model pembelajaran dan media yang tepat. Pada penelitian ini, peneliti akan menerapkan model reciprocal learning dengan alasan model reciprocal learning memberikan kesempatan kepada siswa untuk menggali materi yang akan didiskusikan di kelas, memberikan 
interaksi antara siswa dengan siswa dan siswa dengan guru. Melalui penerapan model reciprocal learning diharapkan pengembangan kecerdasan siswa akan lebih tercapai dan memberikan kontribusi positif pada siswa dalam hal memperoleh pemahaman, memonitor belajar, meningkatkan interaksi, dan partisipasi serta mengembangkan hubungan baru diantara peserta didik.

Pada dasarnya siswa memiliki minat (Sense of Interest) dan dorongan ingin melihat kenyataan (Sense of Reality) seperti yang dijelaskan Suprayogi, dkk (2011:66) bahwa mengingat materi pembelajaran IPS lebih banyak memuat informasi maka upaya mengembangkan kedua potensi tersebut, guru dituntut memiliki kreatifitas dalam mengaktualisasikan kompetensinya terutama untuk mengidentifikasi, menyeleksi, dan menentukan sumber pembelajaran yang menunjang kegiatan belajar dan pembelajaran.

Pada penelitian ini, sumber belajar yang diterapkan adalah media pembelajaran, yaitu media cerita dan metrik ingatan. Media cerita sebagai alat bantu yang digunakan untuk menyampaikan informasi materi pelajaran
IPS, sedangkan metrik ingatan yang dimaksud dalam penelitian ini merupakan sebagai alat bantu mengingat dan menghafal fakta dan konsep pada materi IPS yang diajarkan.

Berpijak pada uraian yang telah disampaikan, penelitian mengarah pada pengembangan ketrampilan sosial siswa pada pembelajaran IPS berbasis keunggulan lokal melalui penerapan reciprocal learning berbantu media cerita dan ingatan"

\section{METODE PENELITIAN}

Penelitian ini merupakan field research (penelitian lapangan) dengan menggunakan mixed methods (metode kombinasi). Mixed methods yang dimaksud dalam penelitian ini adalah penggabungan antara pendekatan penelitian kualitatif dan pendekatan penelitian kuantitatif. Peneliti menggabungkan dua pendekatan dalam penelitian ini dengan tujuan untuk menemukan hipotesis dan juga untuk membuktikan validitas hipotesis tersebut.

Desain penelitian yang digunakan dalam penelitian ini adalah model sequential explaratory (urutan penemuan). Menurut Sugiyono 
(2008:473), Mixed methods model sequential explaratory merupakan metode penelitian yang menggabung metode penelitian kualitatif dan kuantitatif secara berurutan dimana pada tahap pertama penelitian menggunakan metode kualitatif dan pada tahap kedua menggunakan metode kuantitatif.

Sasaran penelitian ini siswa kelas V SD Negeri se-Kecamatan Bae yang menjadi mitra MBS yaitu SD 1 Bacin Kudus, SD 4 Dersalam Kudus, dan SD 1 Panjang Kudus. Permasalahan penelitian ini difokuskan pada pengembangan ketrampilan sosial siswa dalam pembelajaran IPS berbasis keunggulan lokal melalui penerapan reciprocal learning berbantu media cerita dan metrik ingatan.

$$
\text { Pengumpulan data yang }
$$
digunakan dalam penelitian ini menggunakan: 1) metode observasi, 2) wawancara, 3) dokumentasi, dan 4) angket. Metode observasi yang digunakan dalam penelitian ini adalah observasi langsung (direct observation). Observasi langsung menurut Mahmud (2011:170) adalah observasi yang dilakukan tanpa perantara (secara langsung) terhadap objek yang diteliti, seperti mengadakan observasi langsung terhadap proses pembelajaran di kelas. Metode yang digunakan dalam penelitian ini menggunakan wawancara semi terstruktur, yaitu gabungan antara teknik wawancara dengan pedoman wawancara terstruktur dan tidak terstruktur.

Metode dokumentasi digunakan untuk mempelajari membaca dan mencatat apa yang tersirat dan tersurat dalam dokumen, laporan peraturan dan literatur lainya yang relevan dengan peneliti, seperti daftar nama siswa yang akan diperlukan dalam penelitian ini. Metode pengumpulan data yang terakhir yaitu angket yang digunakan dalam penelitian ini adalah angket tertutup dengan menggunakan skala guttman dimana data yang diperoleh berupa data interval atau rasio dikhotomi (dua alternatif).

Teknik keabsahan data dalam penelitian ini menggunakan triangulasi. Teknik triangulasi yang digunakan dalam penelitian ini adalah teknik pemeriksaan dengan memanfaatkan penggunaan sumber berarti membandingkan dan mengecek balik derajat kepercayaan suatu informasi yang diperoleh melalui waktu dan alat yang berbeda. 
Teknik analisis data dalam penelitian ini menggunakan Analisis data kualitatif dalam Matthew B. Miles dan A. Michael Huberman (1992:16-19) terdiri dari tiga alur kegiatan secara bersamaan. Model analisis yang dipergunakan dalam penelitian ini adalah “Analisis Interaksi”, artinya analisis ini dilakukan dalam bentuk interaksi pada tiga komponen tersebut yang digambarkan sebagai berikut:

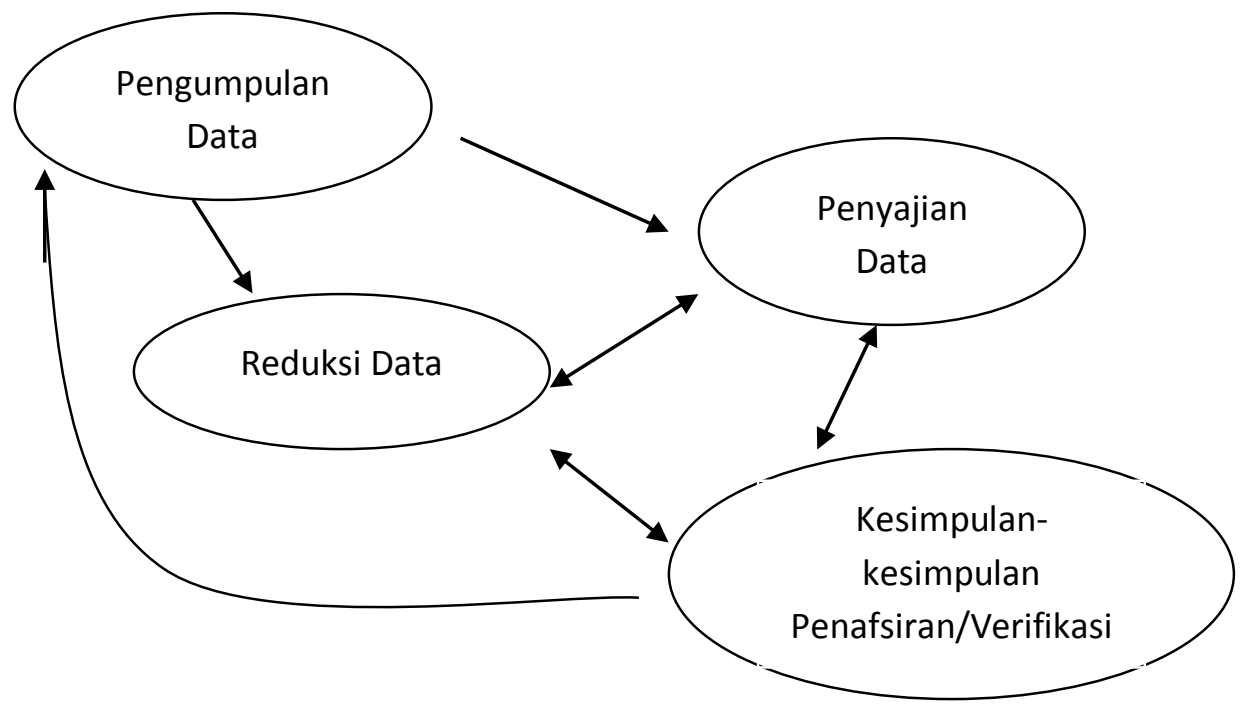

Gambar 4.1 Alur Analisis Interaksi

Sumber: Miles, 1992:20

Berdasarkan gambar 4.1., pada tahap reduksi, data yang diambil dari pengamatan, wawancara, dan dokumen diklasifikasi atau dikategorikan berdasarkan beberapa tema sesuai fokus penelitian. Tahap berikutnya, data yang sudah dikategorikan, disajikan dalam analisis perancangan deretan kolomkolom sebuah matrik untuk data kualitatif dan menentukan jenis dan bentuk data yang disajikan dalam tabel yang ditujukan untuk menyederhanakan data hasil penelitian. Hal ini dilakukan untuk memudahkan peneliti membaca dan memahami hasil penelitian, membandingkan data-data hasil penelitian satu dengan lainnya, dengan demikian peneliti bisa memaknai atau mengartikan data penelitian. Melalui interpretasinya dapat menjelaskan dan memahami gejala sosial yang ditelitinya. Setelah analisis data selesai dan informasi telah diperoleh, hasil-hasilnya harus diinterpretasikan 
guna mencari makna dan implikasi yang luas dari hasil penelitian tersebut.

Verifikasi atau menarik kesimpulan yaitu berupa intisari dari penyajian data yang merupakan hasil dari analisis yang dilakukan dalam penelitian. Kesimpulan adalah tinjauan ulang pada catatan di lapangan atau kesimpulan dapat ditinjau sebagai makna yang muncul dari data yang harus diuji kebenarannya, kekokohannya dan kecocokannya yaitu merupakan validitasnya. Dalam proses ini peneliti membuat tafsiran terhadap data yang sudah diklasifikasikan sesuai dengan landasan teori dan mencoba menghayati keterangan yang diberikan informan. Dalam penelitian ini, penarikan kesimpulan disesuaikan dengan permasalahan yang dikaji dalam penelitian. Dalam penarikan kesimpulan, penelitian juga meninjau ulang pada data sebelumnya dan peneliti berusaha menarik kesimpulan disertai dengan pengujian kebenaran yang disesuaikan validitasnya yaitu triangulasi data.

\section{HASIL PENELITIAN DAN} PEMBAHASAN

Penelitian ini dilaksanakan melalui beberapa tahapan yaitu 1) tahap perizinan, 2) tahap penyusunan perangkat pembelajaran, 3) tahap penyusunan instrumen penelitian, 4) tahap pengumpulan data, dan 5) tahap analisis hasil penelitian.

Tahapan pertama yaitu perizinan, peneliti membuat surat ijin penelitian yang dimulai dari Lembaga Penelitian untuk selanjutnya dilanjutkan untuk mengajukan permohonan ijin ke Dinas Pendidikan terkait sampai pada perizinan ke Sekolah Dasar di Kecamatan Bae sebagai lokasi penelitian.

Tahapan kedua yaitu tahapan penyusunan perangkat pembelajaran dimulai kegiatan kajian literatur dan berdiskusi dengan guru kelas $\mathrm{V}$ sebagai ahli yang berpengalaman dalam pembelajaran IPS di Sekolah Dasar dan Tim Penelitian yang berkaitannya ketrampilan sosial dengan keunggulan lokal khususnya keunggulan lokal Kudus sebagai dasar penelitian dalam proses pembelajaran IPS di dalam penelitian ini.

Kegiatan berikutnya ditahap kedua yaitu pembuatan perangkat pembelajaran IPS dengan menerapkan reciprocal learning berbantu media cerita dan metrik ingatan dalam mengembangkan ketrampilan sosial siswa 
pada pembelajaran IPS berbasis keunggulan lokal dengan menentukan SK dan KD yang akan diteliti. SK yang akan diteliti yaitu menghargai berbagai peninggalan dan tokoh sejarah yang berskala nasional pada masa HinduBudha-Islam, keragaman kenampakan alam dan suku bangsa, serta kegiatan ekonomi di Indonesia dan pada KD mengenal makna peninggalan dan tokoh sejarah yang berskala nasional dari masa Hindu-Budha dan Islam di Indonesia, peneliti memilih SK dan $\mathrm{KD}$ ini dikarenakan sangat sesuai dengan keunggulan lokal yang ada di Kudus. Adapun perangkat pembelajaran IPS tersebut yaitu silabus, RPP, media cerita dan metrik ingatan yang bertemakan peninggalan bersejarah di Kudus, Tokoh berpengaruh dalam sejarah dan perkembangan Kudus, Masjid Kudus sebagai peninggalan sejarah bercorak Hindu-Islam, dan Wisata Budaya Kudus sebagai peninggalan Kebudayaan HinduBudha dan Islam di Kudus.

Tahap ketiga adalah penyusunan instrumen penelitian dimulai dari menyusun lembar observasi ketrampilan sosial siswa yang digunakan untuk mengamati aktivitas belajar siswa terkait dengan ketrampilan sosial yaitu kesadaran situasional, kemampuan membawa diri, autentisitas, kejelasan dan empati. Instrumen yan disusun berikutnya yaitu lembar wawancara siswa yang digunakan untuk mengetahui sejauhmana pemahaman siswa mengenai makna peninggalan dan tokoh sejarah yang berskala nasional dari masa HinduBudha dan Islam di Indonesia terkait dengan keunggulan lokal Kudus dan mengetahui faktor-faktor apa saja yang mempengaruhi penerapan reciprocal learning berbantu media cerita dan metrik ingatan dalam mengembangkan ketrampilan sosial siswa pada pembelajaran IPS berbasis keunggulan lokal. Instrumen terakhir yaitu lembar angket siswa digunakan untuk mengetahui sejauhmana ketrampilan sosial siswa.

Tahap keempat yaitu pengumpulan data. Sesuai dengan sintaks reciprocal learning, pelaksanaan pembelajaran dimulai dari peragaan awal dimana guru meminta empat siswa untuk tampil ke depan kelas untuk memperagakan contoh pembelajaran yang akan dilakukan. Keempat siswa diberi peran yang berbeda-beda yaitu sebagai 
perangkum, penanya, pengklasifikasi dan penduga. Tujuan dari adanya peragaan awal adalah supaya siswa mengerti akan peran yang harus dilakukan berdasarkan cerita keunggulan lokal Kudus.

Langkah berikutnya pembagian peran, guru mengorganisasikan siswa untuk belajar dalam kelompoknya sesuai dengan tugasnya masing-masing, yaitu sebagai perangkum, penanya, pengklasifikasi dan penduga. Tujuan masing-masing siswa mempunyai peranannya sendiri adalah supaya siswa tersebut mulai berlatih untuk mandiri dan bertanggungjawab, serta bagaimana cara bekerjasama dengan temannya. Siswa yang berperan sebagai perangkum bertugas untuk mencatat hal-hal penting yang ada di dalam cerita. Siswa yang berperan sebagai penduga membantu memprediksi apa yang sudah dibaca untuk menyimpulkannya diakhir pembelajaran. Untuk penduga pada pertemuan pertama hasilnya sudah memuaskan, yaitu dari tiga kelompok termasuk sangat baik semua. Siswa yang bertugas sebagai penanya mempunyai peran untuk bertanya kepada kelompok lain terkait dengan cerita yang sudah dibaca dan menjawab jika ada kelompok lain yang bertanya kepada kelompok tersebut. Siswa yang berperan sebagai pengklasifikasi bertugas menyusun atau menemukan bagian-bagian teks yang tidak jelas dan menemukan cara untuk memperjelas kesulitan-kesulitan yang ada.

Langkah terakhir sekaligus awal dari pertemuan kedua, ketiga, dan keempat yaitu pertukaran peran. Melalui cerita lain, yaitu pertemuan pertama dengan cerita "Peninggalan bersejarah di Kudus", pertemuan kedua dengan cerita "Tokoh berpengaruh dalam sejarah dan perkembangan Kudus", pertemuan ketiga dengan cerita "Masjid Kudus sebagai peninggalan sejarah bercorak HinduIslam", dan pertemuan keempat dengan cerita "Wisata Budaya Kudus sebagai peninggalan Kebudayaan Hindu-Budha dan Islam di Kudus", siswa berganti peran, misalnya yang tadinya sebagai penanya, pada cerita selanjutnya atau pertemuan selanjutnya, siswa tersebut mengganti perannya menjadi penduga dan melakukan langkah selanjutnya lagi seperti yang sudah. Pertukaran peran ini dilakukan agar siswa tidak jenuh dengan kegiatannya atau perannya dalam 
kelompok, dan agar siswa bisa untuk dan temuan dalam penelitian ini dapat bekerja di bidang lain (profesional). dilihat pada tabel 1 berikut.

Secara keseluruhan proses pembelajaran berjalan baik. Adapun hasil

Tabel 1 Peningkatan Aktivitas Belajar IPS Melalui Penerapan Reciprocal Learning

\begin{tabular}{|c|c|c|c|}
\hline Pertemuan Ke & SD 1 Bacin Kudus & SD 4 Dersalam & SD 1 Panjang \\
\hline $\mathbf{1}$ & Kurang & Cukup & Kurang \\
\hline $\mathbf{2}$ & Baik & Baik & Baik \\
\hline $\mathbf{3}$ & Baik & Sangat Baik & Sangat Baik \\
\hline $\mathbf{4}$ & Sangat Baik & Sangat Baik & Sangat Baik \\
\hline
\end{tabular}

Sumber: Data Penelitian (2014)

Berdasar tabel 1, secara

keseluruhan proses pembelajaran berjalan baik. Adapun hasil dan temuan dalam penelitian ini, pertama, terjadi peningkatan yang signifikan dalam aktifitas belajar siswa ketika melakukan kerja kelompok, dimana pertemuan pertama masih ada yang kurang, akhirnya pada pertemuan kedua, ketiga dan keempat meningkat sampai kategori sangat baik.

Peningkatan aktivitas belajar ini dibuktikan salah satunya berdasarkan hasil observasi terhadap siswa dengan inisial $\mathrm{t}$ yang pada pertemuan pertama masih belum bisa berkomunikasi dengan

Tabel 2 Peningkatan Ketrampilan Melalui Penerapan Reciprocal Learning Berbantu Media Cerita dan Metrik Dalam Pembelajaran IPS Berbasis Keunggulan Lokal

\begin{tabular}{|c|c|c|c|}
\hline Pertemuan Ke & SD 1 Bacin Kudus & SD 4 Dersalam & SD 1 Panjang \\
\hline $\mathbf{1}$ & 63,33 & 78,84 & 72,65 \\
\hline $\mathbf{2}$ & 70,00 & 78,16 & 77,50 \\
\hline $\mathbf{3}$ & 72,92 & 79,74 & 80,44 \\
\hline $\mathbf{4}$ & 76,25 & 82,37 & 82,21 \\
\hline
\end{tabular}

anggotanya, pada pertemuan kedua anggotanya sudah mau berbicara dengan siswa t, kemudian ada peningkatan kinerja juga, teman-teman $t$ mau memberikan penjelasan ketika $t$ mengalami kebingungan, sehingga kemampuan siswa $\mathrm{t}$ terlihat meningkat dibandingkan dengan pertemuan pertama. Ini berarti ada pengaruh lingkungan dan siswa lain terhadap mental $\mathrm{t}$.

Peningkatan aktivitas belajar dalam penelitian ini diikuti pula dengan hasil peningkatan ketrampilan sosial siswa yang dapat dilihat pada tabel 2 berikut. 
Sumber: Data Penelitian (2014)

Berdasar tabel 2, rata-rata ketrampilan siswa pada awal pertemuan menunjukkan kategori kurang sampai baik, namun pada pertemuan-pertemuan berikutnya menunjukkan kategori baik. Ini berarti pembelajaran IPS untuk mengembangkan keterampilan sosial siswa berhasil.

\section{Keberhasilan peningkatan}

ketrampilan sosial ini juga disebabkan pula adanya antusias siswa ketika mengikuti pembelajaran. Hasil wawancara terhadap siswa yang sebagian besar menjawab senang dan semangat ketika guru menerapkan pembelajaran IPS berbasis keunggulan lokal melalui penerapan reciprocal learning berbantu media cerita dan metrik ingatan dalam mengembangkan ketrampilan sosial siswa. Hal ini berarti antusiame dan apresiasi siswa terhadap pembelajaran mengikis segala perbedaan individu, sehingga pembelajaran menunjukkan adanya peningkatan ketrampilan sosial, meskipun terdapat beberapa faktor-faktor yang mempengaruhi keberhasilan tersebut.

Faktor-faktor yang mempengaruhi pengembangan ketrampilan sosial siswa dalam pembelajaran IPS yaitu faktor dari diri sendiri dan faktor dari lingkungan, antara lain perbedaan individu terutama dalam kesiapan belajar yaitu siswa yang mengalami gangguan disabilitas intelektual, slow learner, disleksia, disgrafia, siswa dengan kerapian kurang, dan kurangnya perhatian dari orang tua

\section{KESIMPULAN}

Penerapan reciprocal learning berbantu media cerita dan metrik ingatan pada pembelajaran IPS berbasis keunggulan lokal dapat diterapkan dalam menggembangkan ketrampilan sosial siswa. Hal ini dibuktikan dengan terjadinya pengembangan ketrampilan sosial siswa pada pembelajaran IPS berbasis keunggulan lokal setelah diterapkannya reciprocal learning berbantu media cerita dan metrik ingatan.

Terdapat beberapa faktor yang mempengaruhi pengembangan ketrampilan sosial antara lain faktor dari diri sendiri dan faktor dari lingkungan antara lain perbedaan individu terutama dalam kesiapan belajar yaitu siswa yang mengalami gangguan disabilitas intelektual, slow learner, disleksia, 
disgrafia, siswa dengan kerapian kurang,

dan kurangnya perhatian dari orang tua.

\section{DAFTAR PUSTAKA}

Abdul Aziz Abdul Madjid. 2001. Mendidik dengan Cerita. Bandung: Remaja F la Karya

Aminuddin. 1987. Pengantar Apresiasi Karya Sastra. Bandung: CV. Sinar Baru

Anitah, Sri. 2009. Media Pembelajaran. Surakarta: Yuma Pustaka bekerja sama dengan FKIP UNS

Antari. Ni Md. Wina. Dkk. 2013. Pengaruh Model Reciprocal Teaching (Pembelajaran Terbalik) Berbantuan Multimedia Terhadap Hasil Belajar IPS Siswa Kelas V SD Gugus I Denpasar Selatan. Artikel. Singaraja: Universitas Pendidikan Ganesha

Arends. Richard I. 2008. Learning To Teach 2. Terjemahan Helly Prajitno Soetjipto dan Sri Mulyantini Soetjipto. Yogyakarta: Pustaka Pelajar

Arifin, Syamsir. 1991. Kamus Sastra Indonesia. Jakarta: Balai Pustaka

Arikunto, Suharsimi. 2006. Prosedur Penelitian Suatu Pendekatan Praktik. Jakarta: PT. Rineka Cipta

Asmani, Jamal Ma'mur. 2012. Pendidikan Berbasis Keunggulan Lokal. Yogyakarta: DIVA Press

Azzet, Akhmad Muhaimin. 2011. Mengembangkan Kecerdasan Sosial Bagi Anak. Yogyakarta: Kata Hati

Black, James A. Dean J Champion. 1992. Metode dan Masalah Penelitian Sosial Bandung: Refika Aditama

Denzin, Norman K., dan Yvonna S. Lincoln. 1994. Handbook of Qualitative Research. Thousand Oaks, London: Sage

Grafura, Lubis. Ari Wijayanti. 2011. Permainan Edukatif Untuk Pembelajaran Atraktif: Untuk Semua Tingkatan Pendidikan Dilengkapi Tip Pembelajaran Atraktif. Jakarta: PT. Prestasi Pustakaraya

Hardyanta, Md. Eric. Dkk. 2013. Penerapan Pembelajaran Terbalik (Reciprocal Teaching) Untuk Meningkatkan Kemampuan Berfikir Kritis Siswa Dalam Pembelajaran IPS di Kelas IV SD. Artikel. Singaraja: Universitas Pendidikan Ganesha

Huda, Miftahul. 2013. Model-Model Pengajaran dan Pembelajaran: Isu-Isu Metodis dan Paradigmatis. Yogyakarta: Pustaka Pelajar 
Mahmud. 2011. Metode Penelitian Pendidikan. Bandung: Pustaka Setia

Miles, Matthew B., dan A. Michael Huberman. 1992. Analisis Data Kualitatif. Terjemahan Tjetjep Rohendi Rohidi. Jakarta:Universitas Indonesia Press

Nurgiyantoro, Burhan. 2009. Teori Pengkajian Fiksi. Yogyakarta: Gadjah Mada University Press

Poerwasarminta, W.J.S. 1976. Kamus Bahasa Indonesia. Jakarta: Balai Pustaka

Sadiman, Arief S. dkk. 1996. Media Pendidikan: Pengertian, Pengembangan dan Pemanfaatannya. Jakarta: PT. RajaGrafindo Persada

Sardijo, Sugandi. Ischaak. 2009. Pendidikan IPS di SD. Jakarta: Universitas Terbuka

Somantri, Muhammad Numan. 2001. Menggagas Pembaharuan Pendidikan IPS. Bandung: PT. Remaja Rosda Karya

Sugiyono. 2008. Metode Penelitian Kuantitatif, Kualitatif, Kombinasi (Mixed Methods). Bandung: Alfabeta

Suprayogi. 2011. Pendidikan Ilmu Pengetahuan Sosial. Semarang: Widya Karya

Tim Pustaka Yustisia. 2007. Panduan Lengkap KTSP (Kurikulum Tingkat Satuan Pendidikan) SD/MI, SMP/MTs, dan SMA/SMK. Yogyakarta: Pustaka Yustisia.

Wahab, Abdul Aziz. 2009. Metode dan Model-Model Mengajar Ilmu Pengetahuan Sosial. Bandung: Alfabeta

Winataputra, Udin Saripudin. 1989. Konsep dan Masalah Pengajaran Ilmu Sosial di Sekolah Menengah. Jakarta: Departemen Pendidikan dan Kebudayaan

Wiryohandoyo, Soedarno dkk.1998. Pendidikan Ilmu Sosial. Semarang: IKIP Semarang

Zaini, Hasyim. Dkk. 2008. Strategi Pembelajaran Aktif. Yogyakarta: Pustaka Insani Madani 